\title{
Comparison of Collaborative Learning Models to Improve Programming Competence
}

\author{
https://doi.org/10.3991/ijoe.v17i10.24865 \\ Krismadinata $^{1}$, Wilda Susanti ${ }^{2}(\varpi)$ \\ ${ }^{1}$ Universitas Negeri Padang, Indonesia \\ ${ }^{2}$ Institut Bisnis dan Teknologi Pelita Indonesia, Indonesia \\ wildallecturer.pelitaindonesia.ac.id
}

\begin{abstract}
The purpose of this research is how collaborative learning strategies should be arranged in three classes as Wang \& Hwang model class, control class and experimental class with different treatments in Algorithm and Programming courses. Three learning strategies were tested to see students' cognitive abilities in computer programming skills. Three collaborative learning scenarios were tested, namely: 1) conventional collaborative learning 2) problem-based collaborative learning using an online environment and 3) inquiry-based collaborative learning also using an online environment. The results of the t-test with the one-way ANOVA test showed that the pretest results of the students' ability levels were not different because they had not been treated. While the results of the t-test with the posttest t-test results obtained a very significant difference in student final results, namely the control class 71.30, Wang \& Hwang model class 73.0 and the experimental class 81.13 . The benefit of the results of this study is that collaborative learning with an inquiry approach allows students to transfer knowledge and does not make lecturers the only source of learning
\end{abstract}

Keywords-Collaborative learning strategy, pre-test, post-test

\section{Introduction}

The development of software and technology raises the need for how the digital world works, as well as the opportunities and risks that arise. The digital world has become a means of creating programming in problem solving and implementing ideas. A series of learning activities that give birth to the process of thinking, finding and solving problems to find answers to questions can be done through the interaction of lecturers and students [1].

Inquiry-based collaborative learning students gain knowledge in mastering concepts and problem solving skills in developing an online learning environment using computers. Learning technology can support students to work collaboratively over long distances and at different times. Educators must give more space to students [2][3]. In accordance with the nature of learning and learning, namely shaping student behavior changes, including cognitive, psychomotor and affective changes, of course, it requires various things to achieve these goals [4]. 
Based on the literature review that has been done there are eight levels of failure in computer programming, namely: 1) not applying the right algorithm, both programming is difficult, 3) ineffective problem solving strategies, 4) inability to solve problems 5) wrong perspective about computer 6) lack of human interaction 7) learning style and motivation and 8) lecturer-centered learning [5]

Two cognitive factors that make learning to program difficult are learning styles and motivation [6][7]. Traditional teaching methods, usually based on lectures and specific programming language syntax and fail to motivate students to engage in programming [8][9][10]. Therefore, it is important to incorporate concept knowledge and strategies for its use in the learning process.

Literature review shows that collaborative programming learning can increase student motivation [10]. Research supports that collaboration is an effective pedagogical feature for programming [11]. According to [12] in his research there was a change in student perceptions about collaborative learning 1) a more pleasant environment 2) more confidence in the peer environment 3 ) increased skills. According to [13] computer-supported collaborative learning can improve thinking skills, social interaction, critical thinking and creativity [14]. Computational thinking involves solving problems based on computer science concepts, designing systems and understanding human behavior and understanding the cognitive processes that underlie collaboration.

Research supports that collaboration is an effective pedagogical feature for programming [11]. According to [12] in his research there was a change in student perceptions about collaborative learning 1) a more pleasant environment 2) more confidence in the peer environment 3) increased skills. According to [13] computer-supported collaborative learning can improve thinking skills, social interaction, critical thinking and creativity. Computational thinking involves solving problems based on computer science concepts, designing systems and understanding human behavior [15] as well as understanding the cognitive processes that underlie collaboration [16].

In its development, several researchers have implemented and developed this collaborative model in learning in order to find solutions to learning problems to increase student competence by implementing the collaborative model steps [17]. Researchers [18] developed a collaborative model with a problem posing strategy by carrying out five steps in learning, namely: 1) Reviewing learning content based on examples and problem submissions; 2) Submitting preliminary problems; 3) Complete problem submissions gradually based on lecturer feedback; 4) Complete initial answers from the problem; and 5) Give a complete answer based on the lecturer's feedback.

In this study, the author wants to try to provide the results of research [18] that the author has done to students at the Pelita Indonesia Faculty of Computer Science with an inquiry-based collaborative model from the research that the author developed. The learning steps that the author takes are: 1) goals and motivation; 2) presenting information; 3) problem identification; 4) forming online discussion groups; 5) inquiry process; 6) applying knowledge; and 7) evaluation. 


\subsection{Collaborative Learning}

Collaborative learning is a joint effort carried out by two or more people, with students or students with lecturers to seek mutual understanding of solutions or create products [19]. Collaborative goals are mostly centered on student exploration or application of material, not just lecturer presentations. Collaborative learning includes functions to prepare assignments, self-study, collaborative learning and task evaluation. The material contains lecture materials and reading resources.

Fig. 1 shows the general collaborative learning model and supported technologies. This model is built by reviewing traditional collaborative learning activities.

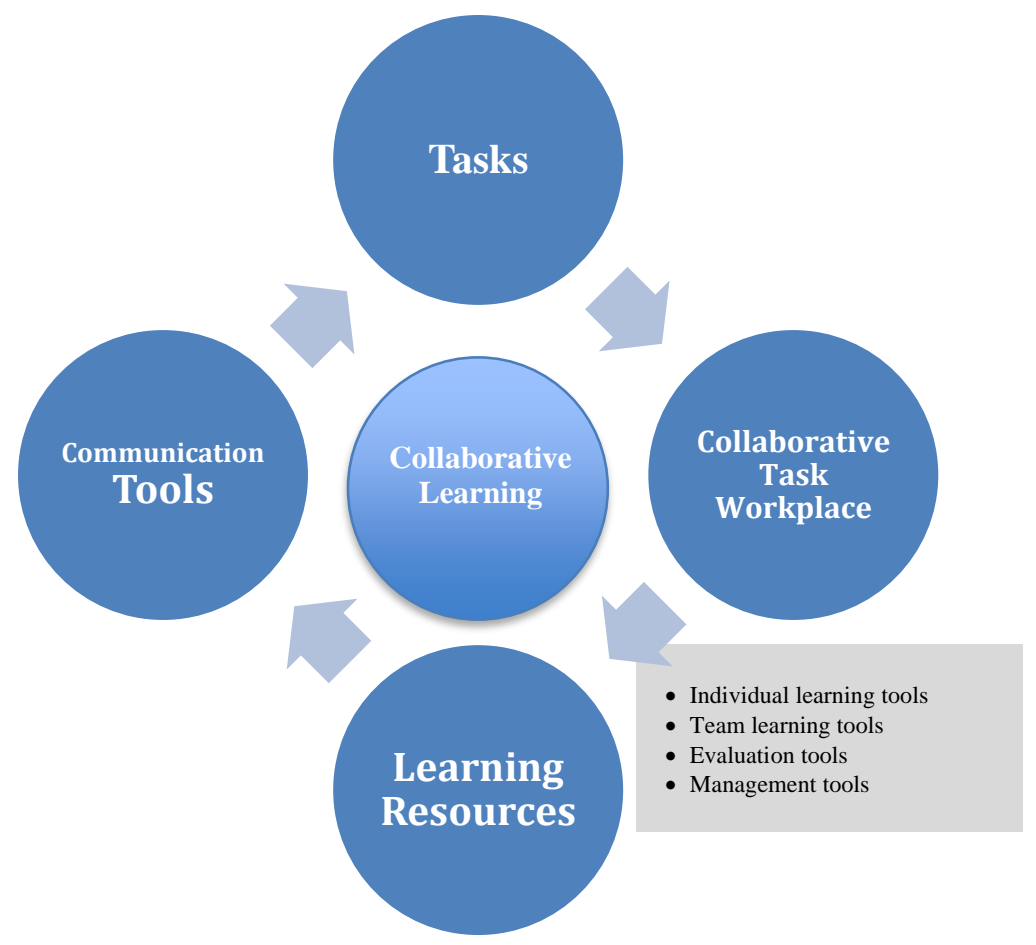

Fig. 1. Learning environment and tools for collaborative learning

\section{Methods}

The experimental research method is a method that is closely related to R\&D, because it is an accurate method to prove the success of the R\&D. The form of the experiment carried out was that three groups were chosen randomly, then given a pretest to determine the initial state, namely the difference between the Wang \& Hwang model group, the control group and the experimental group. A total of 41 students participated in this studydivide the group into three, test group $n=15$, control group $n=16$, model group (Wang \& Hwang, 2017) $\mathrm{n}=15$. 
The subjects to carry out the trial development of the Collaborative learning model to improve student competence based on the Borg \& Gall theory in this study were students who took the Algorithm and Pro-gramming lecture in the second semester at the Informatics Engineering Study Program, Faculty of Computer Science, Pelita Indonesia Institute of Business and Technology. The control class is needed as a comparison of learning outcomes against classes using the Collaborative model that has been developed. The control class in this study includes the class with the old/conventional model and the class that uses the Collaborative model before development based on the step [18].

\section{$3 \quad$ Result and Discussion}

\subsection{Cognitive Test}

The cognitive aspect aims to assess the extent of student mastery of theoretical studies in the course. The results of the cognitive aspects of pretest and posttest control class, collaborative model class (Wang \& Hwang, 2017) and experimental class.

Table 1. Cognitive Aspect Test Results

\begin{tabular}{|l|c|c|c|}
\hline \multicolumn{1}{|c|}{ Class } & N & Mean Pre-test & Mean Post-test \\
\hline Experiment & 15 & 21,83 & 81,13 \\
\hline Control & 16 & 21,03 & 71,30 \\
\hline Model (Wang \& Hwang, 2017) & 15 & 26.03 & \\
\hline
\end{tabular}

The graph of the pre-test score is as follows:

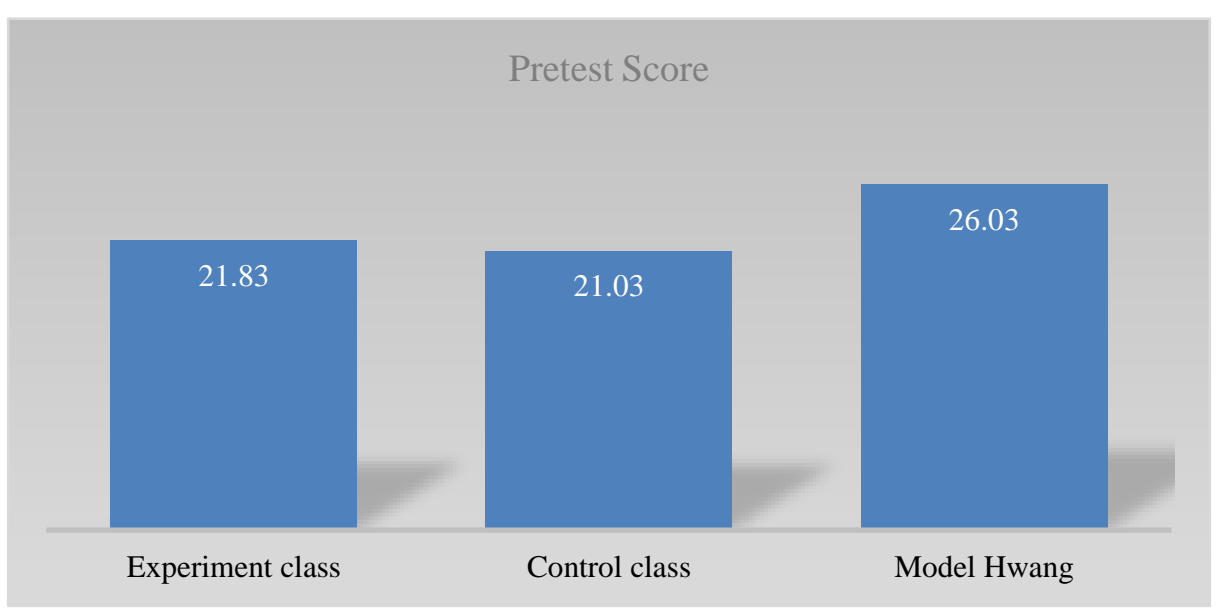

Fig. 2. Pretest experiment class, control class and model class (Wang \& Hwang, 2017) 


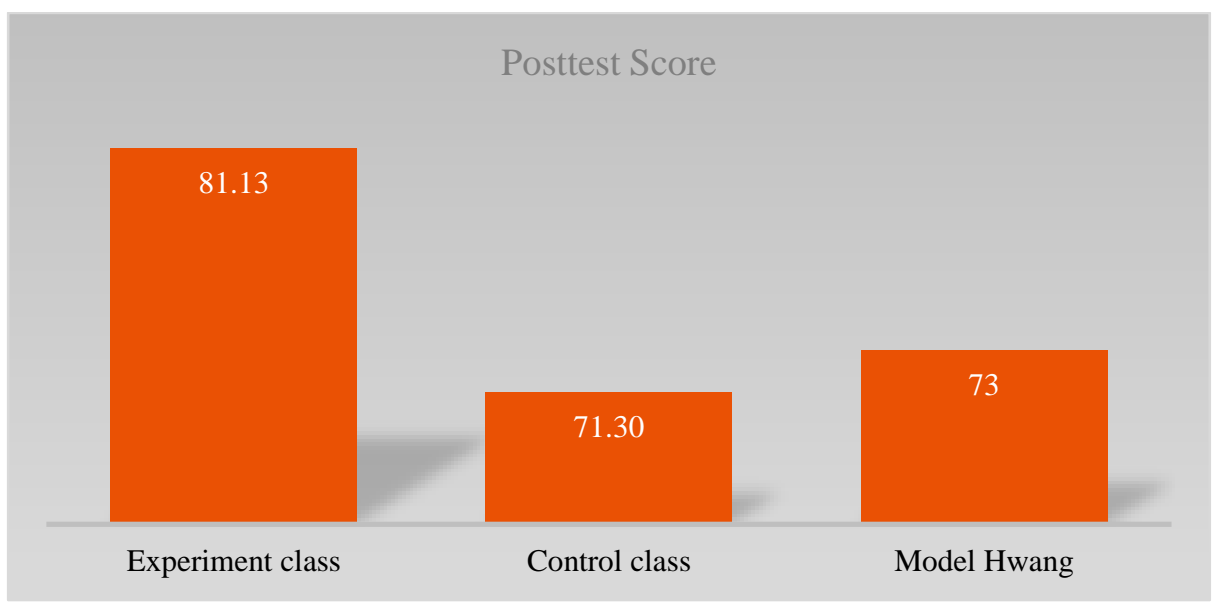

Fig. 3. Posttest Experiment Class, Control Class and Model Class (Wang \& Hwang, 2017)

\subsection{Pre-Test Homogeneity Test}

Homogeneity test is one of the requirements (not absolute) of the independent sample t test. This test aims to assess whether the variance of the student study groups is the same or homogeneous. The homo-geneity test in this study includes the pre-test homogeneity test between the control group and the Col-laborative Model group (Wang \& Hwang, 2017) as well as the homogeneity test of the pre-test control group and the instrument group. This test analyzes student learning outcomes using Levene's test on IBM SPSS Statistic 24. The data is said to be homogeneous if the significance level is greater than 0.05 .

Pre-test Homogeneity Test of Control Group and Collaborative Model Group (Wang \& Hwang, 2017). The results of the homogeneity test with spss, obtained the results of Signification (Sig) Based on Mean of $0.695>0.05$, so that the control group pretest variance and the Collaborative Model group pretest (Wang \& Hwang, 2017)) were the same or homogeneous. The results of the Pretest Homogeneity Test for the Control Group and the Collaborative Model Group (Wang \& Hwang, 2017) with SPSS can be seen in Table 2 .

Table 2. Homogeneity test results

\begin{tabular}{|l|c|c|c|c|}
\hline & Levene Statistic & df1 & df2 & Sig. \\
\hline Pre-test & 0,87 & 1 & 43 & 0,917 \\
\hline Post-test & 0,471 & 1 & 43 & 0,695 \\
\hline
\end{tabular}

Pretest Homogeneity Test Control Group and Experiment Group. Output of the homogeneity test with SPSS above, the significance value (Sig) Based on Mean was $0.798>0.05$, so it can be concluded that the variance of the pre-test of the control group and the pre-test of the experimental group were homogeneous. The results of the Pretest 
Homogeneity test for the Control class and the Experimental Class with SPSS can be seen in Table 3.

Table 3. Results of pre-test homogeneity test for control group and experimental group

\begin{tabular}{|l|c|c|c|c|}
\hline & Levene Statistic & df1 & df2 & Sig. \\
\hline Pre-test & 0,87 & 1 & 43 & 0,917 \\
\hline Post-test & 0,471 & 1 & 43 & 0,695 \\
\hline
\end{tabular}

For the two tests above, the results of the homogeneity test proved to have the same or homogeneous variance. Thus, one of the requirements (not absolute) of the independent sample t test can be fulfilled. In addition to homogeneity data, there are other requirements in using the independent sample $t$ test where the (absolute) requirement is that the data must be normally distributed through the normality test.

\subsection{Pre-Test Normality Test}

Normality Test Pre-test Control Group and Collaborative Model Group (Wang \& Hwang, 2017). Normality test was performed using SPSS with Kolmogorov Smirnov and Shapiro Wilk statistics with a significant level of $=0.05$. The test results can be seen in table 4 .

Table 4. Normality test results

\begin{tabular}{|l|c|c|c|c|c|c|}
\hline & Statistic & Df & Sig. & Statistic & df & Sig. \\
\hline Class & .346 & 31 & .000 & .638 & 31 & .000 \\
\hline Pre-test & .145 & 31 & .096 & .958 & 31 & .257 \\
\hline Post-test & .120 & 31 & $.200^{*}$ & .952 & 31 & .180 \\
\hline
\end{tabular}

From the SPSS results above, it can be stated that the results of normality in the Kolmogorov-Smirnova test obtained a pretest value of 0.96 and a post-test result of $0.200>0.05$, concluded normal data

Normality Test Pre-test Control Group and Instrument Group. The results of the pretest normality test of the control group and the instrument group can be stated that the results of normality in the Kolmogorov-Smirnova test obtained the value of the experimental class on the pretest result of 0.96 and in the control class of $0.200>0.05$, con-cluded normal data.

Table 5. Normality test results

\begin{tabular}{|l|c|c|c|c|c|c|}
\hline & Statistic & Df & Sig. & Statistic & df & Sig. \\
\hline Class & .346 & 31 & .000 & .638 & 31 & .000 \\
\hline Pre-test & .145 & 31 & .096 & .958 & 31 & .257 \\
\hline Post-test & .120 & 31 & $.200^{*}$ & .952 & 31 & .180 \\
\hline
\end{tabular}

* This is a lower bound of the true significance.

a. Lilliefors Significance Correction 
The results of normality in the Kolmogorov-Smirnov test obtained the value of the experimental class on the pretest result of 0.96 and in the control class of $0.200>0.05$, concluded normal data.

\subsection{Test Independent Sample T-Test}

The implementation of the $t$ test can be carried out after carrying out normality and homogeneity tests. The t-test aims to see if there is a difference between the two classes. The hypotheses proposed for this test are:

Ho: There is no difference in the average pretest results of control and experimental class students.

Ha: There is a difference in the average pretest results of control and experimental class students.

Decision making basis:

If the significance value or sig.(2-tailed) $>0.05$, then Ho is accepted and Ha is rejected.

If the significance value or sig. $(2$-tailed) $<0.05$, then Ho is rejected and $\mathrm{Ha}$ is accepted.

To find out that the developed model is better than the control class and model class learning (Wang \& Hwang, 2017), a one-way ANOVA test was conducted. Here are the results.

Table 6. One-way anova test results

\begin{tabular}{|l|l|l|l|c|c|c|c|c|}
\hline & & & & $\begin{array}{c}\text { Sum of } \\
\text { Squares }\end{array}$ & Df & $\begin{array}{c}\text { Mean } \\
\text { Square }\end{array}$ & F & Sig. \\
\hline Pre-Test & Between Groups & (Combined) & Pre-Test & 215.193 & 2 & 107.597 & 3.042 & .058 \\
\hline Pre-tes & 145 & Linear Term & .096 & 124.359 & 1 & 124.359 & 3.516 & .068 \\
\hline Posttest & 120 & 31 & $.200 *$ & 124.359 & 1 & 124.359 & 3.516 & .068 \\
\cline { 2 - 9 } & & & & 90.834 & 1 & 90.834 & 2.568 & .116 \\
\cline { 2 - 9 } & Within Groups & & & 1520.827 & 43 & 35.368 & & \\
\cline { 2 - 9 } & Total & & & 1736.021 & 45 & & & \\
\hline \multirow{5}{*}{ Post-Test } & Between Groups & Combined) & Post-Test & 842.980 & 2 & 421.490 & 17.212 & .000 \\
\cline { 2 - 9 } & & Linear Term & & 496.784 & 1 & 496.784 & 20.287 & .000 \\
\cline { 2 - 9 } & & & & 496.784 & 1 & 496.784 & 20.287 & .000 \\
\cline { 2 - 9 } & & & & 346.196 & 1 & 346.196 & 14.137 & .001 \\
\cline { 2 - 9 } & Within Groups & & & 1052.979 & 43 & 24.488 & & \\
\cline { 2 - 9 } & Total & & & 1895.95 & 45 & & & \\
\hline
\end{tabular}

To see if there are differences in income from the three groups of experimental class, control class and collaborative model (Wang \& Hwang, 2017). We look at the ANOVA table, from that table in the Sig column obtained $\mathrm{P}$ value $(\mathrm{P}$-value $)=0.058$ and 0.000 . Thus, at the level of significance $=0.05$, it rejects Ho, so the conclusion obtained is that there is a significant difference in the average income based on the three groups. 
Post Hoc Tests are used to find out which variables have significant differences. The way to analyze it is to see whether there is an * sign in the Mean Difference col-umn.

The * sign indicates a significant difference in the mean. Examples:

The mean in the experimental class is significantly different from the col-laborative model (Wang \& Hwang, 2017).

The mean in the control class is significantly different from the collaborative model (Wang \& Hwang, 2017). Turkey HSD and Bonferroni lines provide the same information.

Table 7. Normality test results

\begin{tabular}{|l|c|c|}
\hline \multicolumn{1}{|c|}{ Class } & N & Subset for alpha $=\mathbf{0 . 0 5}$ \\
\hline Control & 16 & 1 \\
\hline Experiment & 15 & 21.9507 \\
\hline Model Hwang & 15 & 26.0227 \\
\hline Sig. & & .064 \\
\hline
\end{tabular}

Means for groups in homogeneous subsets are displayed.

a) Uses Harmonic Mean Sample Size $=15.319$.

b) The group sizes are unequal. The harmonic mean of the group sizes is used. Type I error levels are not guaranteed

Table 8. Post-test results

\begin{tabular}{|l|c|c|c|}
\hline \multicolumn{1}{|c|}{ Class } & N & Subset for alpha $=\mathbf{0 . 0 5}$ & Subset for alpha $=\mathbf{0 . 0 5}$ \\
\hline Kontrol & 16 & 71.3094 & \\
\hline Model Hwang & 15 & 73.0000 & 81.1387 \\
\hline Eksperimen & 15 & & 1.000 \\
\hline Sig. & & .615 & \\
\hline
\end{tabular}

Means for groups in homogeneous subsets are displayed.

a) Uses Harmonic Mean Sample Size $=15.319$.

b) The group sizes are unequal. The harmonic mean of the group sizes is used. Type I error levels are not guaranteed

To find out which variables have mean differences, the output of Homogeneous Subsets is used to find out which samples/variables have less significant differences. In the table above, in the subset 1 column there are 2 values of the experimental class variables, controls and other models. This means that the mean of the experimental class, control and other models, does not have a significant difference.

Based on the results of the homogeneity of the significance value of the control class and the collaborative model class (Wang \& Hwang, 2017), the results of the homogeneity carried out in the pretest class were 0.87?0.05 and the posttest was $0.471>0.050$. So it is said to be homogeneous. While the results of the homogeneity of the control group and the experimental group Significance (Sig) Based on Mean of $0.798>0.05$ 
and the results of the posttest test scores of $0,0.93>0.050$, so it can be concluded that the variance of the pretest of the control group and the pretest of the experimental group is homogeneous

The results of the pre-test t-test with the one-way ANOVA test in table 7. The control group, the Collaborative Model group (Wang \& Hwang, 2017) and the experimental group obtained sig values. (2-tailed) of $0.00<0.05$, then according to the basis of decision making in the independent samples T-test, it can be concluded that Ho is rejected $\mathrm{Ha}$ is accepted, which means that there is a difference in the average pretest results of the control group students, the Collaborative Model group (Wang \& Hwang, 2017) and the experimental group. From the results of the T-test with the one-way ANOVA test, it can be concluded that students have the same abilities before there is treatment of the use of inquiry-based online collaborative models in algorithms and programming courses.

The results of the post-test student t-test of the control group, the collaborative model group (Wang \& Hwang, 2017) and the experimental group were obtained based on the group test output obtained a sig value. (2-tailed) of $0.00<0.05$, then according to the basis of decision making in the independent samples T-test, it can be concluded that Ho is rejected $\mathrm{Ha}$ is accepted which means that there is a difference in the average posttest results of the control group students against the collaborative model (Wang \& Hwang, 2017) and the experimental group. From these results it can be said that the three classes have different learning outcomes and it can be stated that there are significant differences in learning outcomes with the control class.

The learning model applied to the Algorithm and Programming course which is the basic course for program learning is the development of the STAD type collaborative model [20] by adopting the model (Wang \& Hwang, 2017) and [21]. Programming training in algorithms and programming courses must be learned through the process of observation, then observations or experiments must be carried out to explain or test the truth of the concept, so that students can feel the concept in context [22]. Algorithms rely on the foundation of student mastery in finding solutions in an orderly, effective and efficient manner, especially those who want to be experts in making computer programs to solve problems. concepts, skills, and level of student motivation.

\section{Conclusion}

Based on the results of research from three classes, namely the control class, the collaborative model class (Wang \& Hwang, 2017) and the experimental class, there is a higher increase in cognition in the experimental class. Class student learning outcomes are higher than the control class and model class (Wang \& Hwang, 2017). This of course can be a model that needs to be applied in universities to improve students' basic programming skills in algorithms and programming courses. 


\section{$5 \quad$ References}

[1] T. A. Eppes, I. Milanovic, and K. Wright, "Improving student readiness for inquiry-based learning: An engineering case study," Int. J. online Biomed. Eng., vol. 16, no. 1, pp. 4-17, 2020, https://doi.org/10.3991/ijoe.v16i01.12051

[2] M. Dobber, R. Zwart, M. Tanis, and B. van Oers, "Literature review: The role of the teacher in inquiry-based education,” Educ. Res. Rev., vol. 22, pp. 194-214, 2017, https:// doi.org/10.1016/j.edurev.2017.09.002

[3] N. F. Hassan, S. Puteh, A. M. Sanusi, and N. H. C. M. Zahid, "Student perspective on technology enabled/enhanced active learning in educational: Rasch measurement model," Int. J. online Biomed. Eng., vol. 16, no. 6, pp. 34-47, 2020, https://doi.org/10.3991/ijoe. $\underline{\mathrm{v} 16 \mathrm{i} 06.13575}$

[4] Y. Hendriyani, D. Ramadhani, T. Nasution, W. Susanti, and U. verawardina, "Examining career development of informatics engineering vocational education students in the industrial revolution 4.0," Int. J. Innov. Creat. Chang., vol. 11, no. 4, pp. 275-298, 2020.

[5] W. Susanti, J. Jama, Krismadinata, D. Ramadhani, and T. Nasution, "An overviuw of the teaching and learning process basic programming in algorithm and programming courses," Turkish J. Comput. Math. Educ., vol. 12, no. 2, pp. 2934-2944, 2021, https://doi.org/ 10.17762/turcomat.v12i2.2332

[6] I. Milne and G. Rowe, "Difficulties in learning and teaching programming - Views of students and tutors," Educ. Inf. Technol., vol. 7, no. 1, pp. 55-66, International Conference On Multimedia And Information And Com 2002, https://doi.org/10.1023/A:1015362 $\underline{608943}$

[7] R. Tandon and P. Ravikumar, "On the difficulty of learning power law graphical models," IEEE Int. Symp. Inf. Theory - Proc., pp. 2493-2497, 2013, https://doi.org/10.1109/isit. $\underline{2013.6620675}$

[8] D.- Berlin and J. Bennedsen, "What do Teachers Teach in Introductory Programming ?," pp. $17-28,2006$.

[9] E. Lahtinen, K. Ala-Mutka, and H. M. Järvinen, "A study of the difficulties of novice programmers," Proc. 10th Annu. SIGCSE Conf. Innov. Technol. Comput. Sci. Educ., pp. 14-18, 2005, https://doi.org/10.1145/1151954.1067453

[10] M. Esteves et al., "The use of Collaborative Virtual Environments to provide student' $\mathrm{s}$ contextualisation in programming To cite this version : - student's contextualisation in programming," 2007.

[11] C. McDowell, L. Werner, H. Bullock, and J. Fernald, "The effects of pair-programming on performance in an introductory programming course," p. 38, 2002, https://doi.org/10. $1145 / 563517.563353$

[12] D. T. \& P. Roe and Queensland, "Collaborative Learning - towards a solution for novice programmers," Comput. Educ. Conf. Conf. Res. Pr. tice Inf. Technol., vol. 78, pp. 147-153, 2008, [Online]. Available: https://eprints.qut.edu.au/17818/1/c17818.pdf

[13] A. W. W. Ma, "Computer Supported Collaborative Learning and Higher Order Thinking Skills: A Case Study of Textile Studies," Interdiscip. J. e-Skills Lifelong Learn., vol. 5, pp. 145-167, 2009, https://doi.org/10.28945/69

[14] W. Susanti, D. Sukrianto, and D. Ramadhani, "Pengaruh Model Discovery Learning dalam Kemampuan Berpikir Kritis dan Cognitif Mahasiswa Program Studi Sistem Informasi," vol. 20, no. 3, 2020, https://doi.org/10.24036/invotek.v20i3.742

[15] S. Grover and R. Pea, "Computational Thinking in K-12: A Review of the State of the Field," Educ. Res., vol. 42, no. 1, pp. 38-43, 2013, https://doi.org/10.3102/0013189X12463051 
[16] A. Soller et al., "Workshop on designing computational models of collaborative learning interaction," Lect. Notes Comput. Sci. (including Subser. Lect. Notes Artif. Intell. Lect. Notes Bioinformatics), vol. 3220, p. 915, 2004, https://doi.org/10.1007/978-3-540-301394

[17] E. Hendarwati et al., "Collaborative Problem Based Learning Integrated with Online Learning," vol. 16, no. 13, pp. 29-39.

[18] X. M. Wang and G. J. Hwang, "A problem posing-based practicing strategy for facilitating students' computer programming skills in the team-based learning mode," Educ. Technol. Res. Dev., vol. 65, no. 6, pp. 1655-1671, 2017, https://doi.org/10.1007/s11423-017-9551-0

[19] W. Kwok, "Using CMC to enhance students' collaborative learning," 1992, [Online]. Available: http://hub.hku.hk/handle/10722/31165

[20] R. . Slavin, “Cooperative Learning,” Bandung Penerbit Nusa Media., 2015.

[21] M. Restrepo, M. Lelea, A. Christinck, C. Hülsebusch, and B. Kaufmann, "Collaborative learning for fostering change in complex social-ecological systems: a transdisciplinary perspective on food and farming systems," Knowl. Manag. Dev. J., vol. 10, no. 3, pp. 3859, 2014.

[22] N. Orion, "A holistic approach for science education for all," Eurasia J. Math. Sci. Technol. Educ., vol. 3, no. 2, pp. 111-118, 2007, https://doi.org/10.12973/ejmste/75382

\section{Authors}

Krismadinata is received the B.Eng. degree from Andalas University, Padang, Indonesia in 2000 and the M.Eng. degree from the Institute of Technology, Bandung, Indonesia, in 2004, and the Ph.D degree from the University of Malaya, Kuala Lumpur, Malaysia, in 2012, and Post-Doctoral at UMPEDAC in 2012/2014. He has been a visiting researcher in some universities in Malaysia and India. He is currently a Senior Lecturer with the Department of Electrical Engineering, Universitas Negeri Padang, Indonesia, where he is also the Director of the Energy Research Center Universitas Negeri Padang. His research interests include power electronics, control system, Renewable Energy. Dr. Kris involves as reviewer in many international journals in electrical engineering field-present (E-mail: krisma@ft.unp.ac.id).

Wilda Susanti is Wilda Susanti completing a Bachelor of Informatics Engineering at STMIK-AMIK Riau in 2007. Obtained a Master's degree in Computer at Putra Indonesia University (UPI) Computer Science Postgraduate Program YPTK Padang in 2008 and a Doctorate degree at Padang State University in 2021. PNS Lecturer LLDIKTI X dpk Institute of Business and Technology Pelita Indonesia Faculty of Computer Science Department of Informatics since 2008-present. Served as head of the Information and Communication Technology Unit of the Pelita Indonesia Institute of Business and Technology. Research interest in Databases, Information Systems and E-Learning.

Article submitted 2021-06-18. Resubmitted 2021-07-19. Final acceptance 2021-07-21. Final version published as submitted by the authors. 